\title{
A CONTRIBUIÇÃO DO PRONAF PARA O DESENVOLVIMENTO RURAL: UMA ANÁLISE DOS SEUS EFEITOS E DESDOBRAMENTOS PARA OS ASSENTADOS RURAIS NOS MUNICÍPIOS DE TEODORO SAMPAIO E CAIUÁ - SP
} PRONAF'S contribution to rural development: an analysis of its effects and developments for rural
settlements in the municipalities of Caiuá and Teodoro Sampaio - SP

La contribución del PRONAF para el desarrollo rural: un análisis de sus efectos y desarrollo para los asentados rurales en los municipios de Teodoro Sampaio y Caiuá - SP

Jânio Gomes do Carmo

Universidade Estadual Paulista - UNESP carmojanio@hotmail.com

Evandro Cesar Clemente

Universidade Federal de Goiás - regional de Jataí evandrospfc@hotmail.com

Artigo recebido para publicação em 14/04/2018 e aceito em 25/05/2018

DOI: 10.12957/tamoios.2018.32171

\section{Resumo}

O reconhecimento oficial dos agricultores familiares ocorreu somente nos anos 1990, com o lançamento do Programa Nacional de Fortalecimento da Agricultura Familiar (PRONAF). A mobilização dos movimentos sociais foi crucial nisso. O programa possibilita acesso a recursos destinados ao custeio das safras e investimentos a juros acessíveis aos distintos beneficiários, garantindo o financiamento da produção e a estruturação dos lotes e, consequentemente, a ampliação da renda. Porém, verificou-se que os assentados recebem um montante bastante reduzido, pelo fato de não atenderem às exigências e garantias do sistema financeiro. O objetivo da pesquisa foi analisar os efeitos do PRONAF nos assentamentos rurais dos municípios de Caiuá e Teodoro Sampaio, que apresentam predomínio de assentados em suas respectivas populações rurais, averiguando se o acesso ao crédito tem promovido melhorias nas condições de vida dos assentados. Caiuá conta com sete assentamentos rurais e Teodoro Sampaio possui 21 assentamentos, ocupados por 1.407 famílias. De modo distinto dos agricultores familiares capitalizados, o volume destes recursos direcionados aos assentados é pequeno e estes enfrentam dificuldades para acessá-los, devido aos baixos rendimentos monetários obtidos nos lotes, à reduzida integração ao mercado e à baixa organização social.

Palavras Chave: Políticas Públicas, PRONAF, Assentamentos rurais e Desenvolvimento rural.

\begin{abstract}
The official recognition of family farmers occurred only in the 1990s, with the release of National Program for Fortification Family Farming (PRONAF). The mobilization of social movements was crucial in this context. The program allows access to resources for the costing of crops and investments at affordable interest to the different beneficiaries, guaranteeing the financing of production and investments that allow the structuring of the lots and, consequently, the increase of the income obtained there. However, it was found that the settlers receive a very small amount, because they do not meet the demands and guarantees of the financial system. The objective of the study was to analyze the effects of PRONAF on the rural settlements in the municipalities of Caiuá and Teodoro Sampaio, which show a predominance of settlers in their respective rural populations, ascertaining if access to credit has promoted improvements in the living conditions of the settlers. Caiuá has seven rural settlements and Teodoro Sampaio has 21 settlements, occupied by 1,407 families. Unlike the family farmers capitalized, the volume of these resources directed to the settlers is small and they face difficulties to access them, due to the low monetary income obtained in the lots, the low market integration and the low social organization.
\end{abstract}

Key words: Public Policies, PRONAF, Rural Settlements and Rural Development. 


\section{Resumen}

El reconocimiento oficial de los agricultores familiares ocurrió solamente en los años 1990, con el lanzamiento del Programa Nacional de Fortalecimiento de la Agricultura Familiar (PRONAF). La movilización de los movimientos sociales fue crucial en ello. El programa permite acceso a recursos destinados al costeo de las cosechas e inversiones a intereses accesibles a los distintos beneficiarios, garantizando el financiamiento de la producción y de inversiones que posibilitan la estructuración de los lotes y, consecuentemente, la ampliación de la renta obtenida allí. Sin embargo, se verificó que los asentados reciben una cantidad bastante reducida, por el hecho de no atender a las exigencias y garantías del sistema financiero. El objetivo de la investigación fue analizar los efectos del PRONAF en los asentamientos rurales de los municipios de Caiuá y Teodoro Sampaio, que presentan predominio de asentados en sus respectivas poblaciones rurales, averiguando si el acceso al crédito ha promovido mejoras en las condiciones de vida de los asentados. Se cierra con siete asentamientos rurales y Teodoro Sampaio posee 21 asentamientos, ocupados por 1.407 familias. De manera distinta a los agricultores familiares capitalizados, el volumen de estos recursos dirigidos a los asentados es pequeño y éstos enfrentan dificultades para acceder a ellos, debido a los bajos rendimientos monetarios obtenidos en los lotes, a la reducida integración al mercado ya la baja organización social.

Palabras clave: Políticas Públicas, PRONAF, Asentamientos rurales y Desarrollo rural.

\section{INTRODUÇÃO}

O reconhecimento oficial dos agricultores familiares ocorreu somente em meados dos anos 1990 com o lançamento do Programa Nacional de Fortalecimento da Agricultura Familiar (PRONAF). Cumpre ressaltar que, seguindo as diretrizes do Banco Mundial, o programa foi concebido para ter como foco os "agricultores familiares", uma terminologia que se pretende referir àqueles que apresentam considerável capitalização financeira, uso de tecnologia e estão fortemente integrados ao mercado, desconsiderando as demais formas de produção familiar existente no vasto e heterogêneo campo brasileiro, como as que estão mais centradas na produção para o autoconsumo, com baixa utilização de tecnologia e menor vinculação ao mercado, como grupos indígenas, remanescentes de quilombos, caiçaras, ribeirinhos, assentados, dentre outros.

A partir dos anos 1990, as políticas públicas direcionadas para o espaço rural brasileiro apresentaram um processo diferenciado, abordando a sua lógica de desenvolvimento e execução, estruturação e formas que desencadearam na abordagem territorial, materializadas com as alterações no PRONAF-Infraestrutura e Serviços Municipais, ainda durante o governo do FHC (1997-2002). No governo Lula, os programas com enfoque territorial foram fortalecidos com a criação da Secretaria de Desenvolvimento Territorial (SDT) no ano de 2003. Tais mudanças buscavam atender à população rural mais vulnerável.

O interesse em estudar essa política pública decorre desta ser a única política federal específica que atende, com recursos financeiros e linhas de crédito, aos agricultores familiares em suas diferentes linhas de atuação, repercutindo nos distintos resultados e efeitos sobre os assentados rurais, que ocupam $57,25 \%$ em Caiuá e $86,04 \%$ em Teodoro Sampaio da população rural desses municípios.

Compreende-se que neste estágio do capitalismo, em virtude da robótica e da automação, a indústria não tenha mais capacidade de gerar empregos em muitos dos pequenos municípios do interior. Uma alternativa é o fortalecimento da agricultura familiar, que tem significativa capacidade distributiva em gerar emprego e renda, além de reunir melhores condições para exercer a sustentabilidade ambiental, tão propalada atualmente em face da vultosa escalada da degradação ambiental (CLEMENTE, 2011).

Deste modo, a promoção do desenvolvimento rural em municípios como Teodoro Sampaio e Caiuá, que são de pequeno porte, apresenta forte dependência de suas economias na prática das atividades agrícolas e do significativo número de assentamentos rurais. Para esse segmento, é de fundamental importância o apoio oficial por meio de políticas públicas, com objetivo de geração de renda e emprego às famílias rurais, que por extensão e consequência, pode até contribuir na dinamização da economia urbana dos municípios, aquecendo o setor de comércio e serviço local.

Visando contribuir com a análise do desenvolvimento rural, a presente pesquisa foi desenvolvida nos municípios de Teodoro Sampaio e Caiuá que, conjuntamente, possuem 28 assentamentos rurais, ocupados por 1.407 famílias que dependem do conjunto de políticas públicas oficiais para o desenvolvimento das atividades agropecuárias para a sobrevivência e permanência no campo. 
Dessa forma, a pesquisa ora apresentada tem por objetivo analisar os efeitos do Programa Nacional de Fortalecimento da Agricultura Familiar (PRONAF), a partir dos subsídios concedidos às famílias assentadas.

\section{OBJETIVO}

O principal objetivo dessa pesquisa é averiguar as possíveis mudanças no direcionamento de políticas públicas às famílias assentadas nos municípios de Teodoro Sampaio e Caiuá - SP. Dessa maneira, a proposta principal é caracterizar os efeitos do PRONAF nos assentamentos rurais dos municípios.

\section{PROCEDIMENTOS METODOLÓGICOS}

A pesquisa desenvolveu - se a partir de leituras sobre a temática a respeito do processo de ocupação do Pontal do Paranapanema, políticas públicas, o conceito de agricultura familiar, formação dos assentamentos rurais, em específico o PRONAF, entre outros. Os dados foram obtidos por meio de levantamento de informações na Fundação Instituto de Terras do Estado de São Paulo (ITESP), em publicações do Instituto Brasileiro de Geografia e Estatística (IBGE) e também no Censo Agropecuário de 2006. Posteriormente, realizou-se 27 entrevistas, sendo 17 com "pessoas - chave" nos assentamentos, isto é, os vice-presidentes e presidentes de associações de produtores rurais dos municípios pesquisados que residiam nos lotes, e ainda seis representantes do poder público municipal (secretários de agricultura, planejamento, educação), dois técnicos e dois presidentes do Conselho municipal de Desenvolvimento Rural, que contribuíram para o desenvolvimento e andamento dessa política pública nos municípios..

A pesquisa foi estruturada com enfoque qualitativo, tendo como base os dados e informações extraídos das entrevistas realizadas com assentados e "pessoas-chave" nos dois municípios analisados. Buscamos, por meio da utilização desta técnica, respostas para nossos questionamentos iniciais. Para isso, elaboramos um roteiro semiestruturado, o qual nos guiou durante a realização das entrevistas. Deixamos as entrevistas transcorrerem e, ao longo delas, fomos questionando os entrevistados, com questões relevantes, conforme o roteiro previamente elaborado. Os direcionamentos realizados ao longo das entrevistas tiveram como meta apreender um volume maior de informações suficientes para responder aos questionamentos iniciais.

Seguimos as orientações de Colognese e Melo (1998) que ressaltam que a técnica da entrevista na pesquisa social pode ser definida através da interação social, em que o entrevistador busca coletar informações diversas do entrevistado.

Para Cedro (2011), essa conversa deve ser solta e direcionada, de forma que os dados possam ser coletados conforme o problema formulado a partir do objeto da pesquisa. Buscou-se através da técnica de diversificação e saturação a obtenção das informações nas amostras (CAMARGO e GELIN, 1974 apud MARRE, 1991). Para a diversificação, entrevistou-se 27 sujeitos entre secretários de governo e assentados rurais nos municípios de Teodoro Sampaio e Caiuá. Buscou-se, assim a saturação, ou seja, o limite das informações coletadas por meio do depoimento dos sujeitos, isto é, o momento que as informações começaram a ficar repetitivas com as entrevistas.

Usou-se um gravador durante as entrevistas, sob o consentimento dos sujeitos entrevistados. Ao término da pesquisa de campo realizou-se a transcrição e a catalogação das informações. Assim, buscou-se mediante o uso da técnica de codificação a maior absorção das informações qualitativas (COLOGNESE e MELO, 1998), com base no tema e em alguns conceitos. Nesse caso, ao adotar-se esse procedimento metodológico, observou-se a aproximação do tema abordado sem deixar de fora os sujeitos, os quais foram as vozes desta pesquisa. Atentamos nossas ações para as diferentes interpretações realizadas pelos sujeitos ao relatarem o lugar e a realidade dos assentamentos e também dos municípios em que a pesquisa foi desenvolvida.

Com base nos dados e nas informações, foi possível estabelecer comparações com as informações complementares, sobre o PRONAF, tecer análise acerca das semelhanças e diferenças entre os produtores assentados e os dois municípios pesquisados. A leitura empírica da realidade nos municípios de Caiuá e Teodoro Sampaio foi crucial para o entendimento e a compreensão no que tange ao acesso às políticas públicas pelos assentados da reforma agrária.

\section{LOCALIZACÃo E CARACTERÍSTICAS dOS MUNICÍPIOS DE CAIUÁ E TEODORO SAMPAIO}

Localizados no Pontal do Paranapanema, Teodoro Sampaio possui uma extensão territorial de $1.556,670 \mathrm{~km}^{2}$ e Caiuá $549,891 \mathrm{~km}^{2}$, o que equivale a aproximadamente $17,62 \%$ e $6,22 \%$ da extensão total da região do Pontal do Paranapanema, que possui $8.822 \mathrm{~km}^{2}$. Os dois municípios apresentam baixa 
densidade demográfica, sendo, 13,74 hab./km², e 9,41 hab./km², respectivamente, conforme os dados do IBGE (2010).

Historicamente estes municípios, assim como a região denominada Pontal do Paranapanema, se caracterizaram por apresentar forte concentração fundiária, com grandes propriedades dedicadas à pecuária de corte, que por sua vez, constitui-se numa atividade que estabelece baixo dinamismo econômico. Caiuá destaca-se pela presença da pecuária de corte e de leite, todavia, em Teodoro Sampaio, além da pecuária de corte e leite, há destaque para a atividade Sucroalcooleira, pelo fato de possuir uma usina ali instalada. Assim, conclui-se que, os dois municípios são essencialmente agropecuários, com baixa expressividade das atividades urbanas.

Em Teodoro Sampaio há algumas agroindústrias, bem como uma unidade da Odebrecht Agroindustrial (antiga Destilaria Alcídia) que produz açúcar e álcool e o Laticínio de Quatá, que pasteuriza o leite in natura e produz queijos, iogurtes e outros derivados de leite. Salienta-se ainda que, o comércio e os serviços da cidade de Teodoro Sampaio suprem parcialmente as necessidades da população urbana e rural, já que o município de Presidente Prudente é que centraliza o comércio e serviços, inclusive os de maior complexidade.

Ambos os municípios possuem um significativo número de estabelecimentos rurais com área inferior a 20 hectares (75,95\% do total em Caiuá e 49,79\% do total em Teodoro Sampaio), que ocupam somente $16,38 \%$ ( 7.861 ha) e 9,36\% (7.998 ha), do total de área destinada para esse grupo, respectivamente. Isso demonstra e reforça a tese de que, mesmo com a implantação dos assentamentos rurais nos municípios, ainda há o predomínio de grandes e médias propriedades rurais, não sendo suficiente para de fato, desconcentrar a propriedade da terra. Mesmo com esse baixo percentual, é notório o direcionamento de políticas públicas para este grupo como por exemplo, o Programa Nacional de Fortalecimento da Agricultura Familiar (PRONAF), pelo fato de concentrarem as populações que, via de regra, enfrentam maiores dificuldades para permanecerem no espaço rural, por exemplo, os assentados rurais.

A implantação de áreas de assentamento representa a expansão das pequenas unidades de produção no campo e ainda, passa a requerer o direcionamento de recursos oficiais via políticas públicas. Apesar da expressiva política de assentamentos ocorrida nos anos 1990, por sinal, pouco difundida nos últimos anos, os dois municípios ainda apresentam uma forte presença de grandes propriedades rurais, sobretudo, àquelas, cujas dimensões se encontram acima de 500 hectares.

A área média dos estabelecimentos era de 84,81 ha em Teodoro Sampaio e de 73,14 ha em Caiuá, de acordo com os dados do Censo Agropecuário no ano de 2006, conforme se verifica na Tabela 1.

Tabela 1 - Número e área dos estabelecimentos agropecuários dos municípios de Teodoro Sampaio e Caiuá, por grupos de área

\begin{tabular}{r|r|r|r|r|r|r}
\hline Estrato de área & \multicolumn{3}{|c|}{ Caiuá } & \multicolumn{3}{|c}{ Teodoro Sampaio } \\
\cline { 2 - 8 } (Em hectares) & \multicolumn{1}{|c|}{} & \multicolumn{1}{c|}{$\begin{array}{c}\text { de } \\
\text { Área }\end{array}$} & & & Área (ha) & \multicolumn{1}{c}{$\begin{array}{c}\text { de } \\
\text { Área }\end{array}$} \\
\hline < 5 hectares & 8 & 14 & 0,03 & 18 & 53 & 0,06 \\
\hline de 5 a menos 10 ha & 61 & 515 & 1,07 & 38 & 310 & 0,37 \\
\hline de 10 a menos 20 ha & 430 & 7.332 & 15,25 & 431 & 7.635 & 9,20 \\
\hline de 20 a menos 50 ha & 87 & 2.572 & 5,35 & 407 & 9.789 & 11,80 \\
\hline de 50 a menos 100 ha & 18 & 1.316 & 2,73 & 19 & 1.392 & 1,68 \\
\hline de 100 a menos 200 ha & 12 & 1.630 & 3,39 & 17 & 2.154 & 2,60 \\
\hline de 200 a menos 500 ha & 20 & 6.292 & 13,09 & 21 & 7.118 & 8,58 \\
\hline de 500 a menos 1000 ha & 9 & 6.792 & 14,13 & 21 & 31.798 & 38,33 \\
\hline De 1000 ha e mais & 12 & 21.592 & 44,93 & 6 & 22.704 & 27,37 \\
\hline Total & $\mathbf{6 5 7}$ & $\mathbf{4 8 . 0 5 5}$ & $\mathbf{1 0 0}$ & $\mathbf{9 7 8}$ & $\mathbf{8 2 . 9 5 3}$ & $\mathbf{1 0 0}$ \\
\hline
\end{tabular}

Fonte: FIBGE Censo Agropecuário, 2006.

Dentre os estabelecimentos com áreas superiores a 500 ha, apenas 21 ocupavam 59,06\% da área total dos estabelecimentos do município de Caiuá ( 28.384 ha). Teodoro Sampaio possuía 27 estabelecimentos com áreas superiores a 500 hectares, os quais concentram $65,7 \%$ da área total dos estabelecimentos do município (54.502 ha), de acordo com o Censo Agropecuário do IBGE de 2006. Verifica-se que, ambos os municípios concentram áreas de maior dimensão territorial, 30 estabelecimentos no estrato entre 500 ha e menos de 1.000 ha, sendo 14,13\% (6.792) em Caiuá e 38,33\% (31.798) em Teodoro Sampaio e 18 com áreas superiores a 1.000 ha, representados na seguinte ordem, 44,93\% (21.592) e 27,37\% (22.704), de acordo com os dados do Censo Agropecuário do IBGE, referentes ao ano de 2006.

Os estabelecimentos situados no estrato de 50 e menos de 500 hectares perfaziam apenas 7,6\% do número total e ocupavam 19,22\% (9.238 ha) da área total dos estabelecimentos em Caiuá, no ano de 
2006. Em Teodoro Sampaio, esse grupo totalizava 5,82\% do número de estabelecimentos e 12,85\% (10.664 ha) da área total ocupada. Destacamos que a pecuária bovina é a principal atividade explorada nos estabelecimentos de diferentes dimensões, uma vez que, nos assentamentos rurais e nas pequenas propriedades, sobressai a atividade leiteira. Já nos médios e grandes estabelecimentos destacam-se a pecuária de corte e a cana-de-açúcar.

As áreas de pastagens cobriam 44,74\% da área total dos estabelecimentos agropecuários do município de Teodoro Sampaio e 75,72\% de Caiuá, de acordo com os dados do Censo Agropecuário (IBGE, 2006). As áreas de lavouras temporárias e permanentes representavam $15,71 \%$ e $4,71 \%$ da área total dos estabelecimentos agropecuários dos dois municípios, respectivamente, perfazendo o montante de 21.447 hectares em Teodoro Sampaio e de 2.594 hectares em Caiuá. As lavouras concentram-se, principalmente no cultivo de alimentos básicos, por exemplo, milho (320 ha), feijão (600 ha) e mandioca (40 ha), cultivadas principalmente na porção sul do município de Caiuá. No município de Teodoro Sampaio, as lavouras centralizam-se nas porções oeste e norte, destacando-se o feijão (100 ha), o milho (410 ha) e a mandioca (96 ha). A produção de lavouras é realizada basicamente pela população assentada dos dois municípios.

Todavia, por apresentarem condições mais vulneráveis, os assentados rurais não conseguem se adequar totalmente às exigências do mercado e dos bancos, mesmo recebendo incentivos financeiros do Governo Federal, por exemplo, do PRONAF.

Atualmente há 28 assentamentos rurais nos dois municípios estudados, sendo sete em Caiuá, com 532 famílias, perfazendo $18,56 \%$ da área total do município e 21 em Teodoro Sampaio, com 875 famílias instaladas em $10,56 \%$ da área total do município, espacializados nas regiões norte, noroeste e oeste desse município, de acordo com as informações do Instituto de Terras do Estado de São Paulo (ITESP), apresentados na Tabela 2.

Tabela 2 - Número e área total ocupada por assentamentos rurais nos municípios de Teodoro Sampaio e

\begin{tabular}{c|r|r}
\multicolumn{3}{c}{ Caiuá-SP } \\
\hline Municípios & \multicolumn{1}{c}{ Teodoro Sampaio } & \multicolumn{1}{c}{ Caiuá } \\
\hline Área total (ha) & $219.798,52$ & $57.789,17$ \\
\hline $\mathbf{N}^{\mathbf{0}}$ de Assentamentos & 21 & 7 \\
\hline Área de assentamento (ha) & $23.650,03$ & 10.732 \\
\hline Área assentada (\%) & 10,76 & 18,56 \\
\hline \multicolumn{2}{r}{ Fonte: Censo Demográfico-FIBGE, 2010. }
\end{tabular}

O efetivo populacional dos assentamentos rurais representa $86,04 \%$ da população rural teodorense e $57,25 \%$ da caiuense, que se encontram espacialmente nas regiões norte e oeste, de acordo com as informações do ITESP, apresentados na Tabela 3.

Tabela 3 - População total, população rural e população assentada em projetos de reforma agrária nos municípios de Teodoro Sampaio e Caiuá - SP

\begin{tabular}{c|r|r}
\hline Municípios & Teodoro Sampaio & \multicolumn{1}{c}{ Caiuá } \\
\hline Pop. Total & 21.386 & 5.039 \\
\hline Pop. Rural & 4.021 & 1.930 \\
\hline Pop. Assentada $*$ & 3.460 & 1.780 \\
\hline Pop. Rural Assentada $(\%) * *$ & 86,04 & 57,25 \\
\hline
\end{tabular}

Fonte: Fundação Instituto de Terras do Estado de São Paulo-(ITESP), 2012.

* população assentada calculada com base no número de integrantes familiares (número total de famílias assentadas multiplicado por quatro, de acordo com os técnicos do ITESP).

** porcentagem da população assentada calculada do total da população rural. 


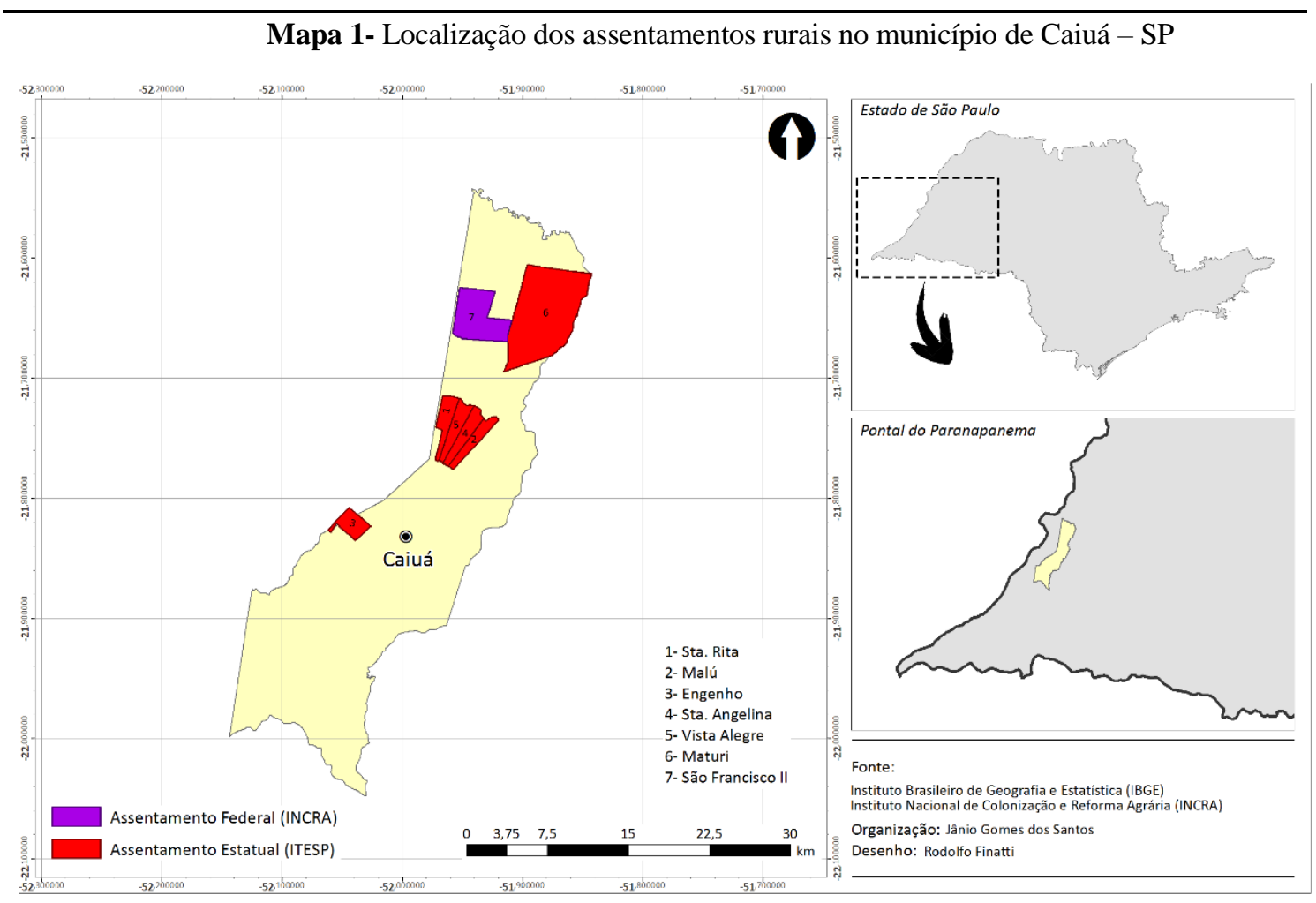

Dentre os assentamentos rurais instalados nos referidos municípios, 26 foram instalados pelo Instituto de Terras do Estado de São Paulo (ITESP), sendo seis em Caiuá e 20 em Teodoro Sampaio e, somente dois, o Assentamento Ribeirão da Água Sumida, em Teodoro Sampaio e o Assentamento Luís Moraes Neto, em Caiuá, foram implantados pelo Governo Federal, por intermédio do Instituto Nacional de Colonização e Reforma Agrária (INCRA), conforme mostram os Mapas 1 e 2.

Mapa 2- Localização dos assentamentos rurais no município de Teodoro Sampaio - SP

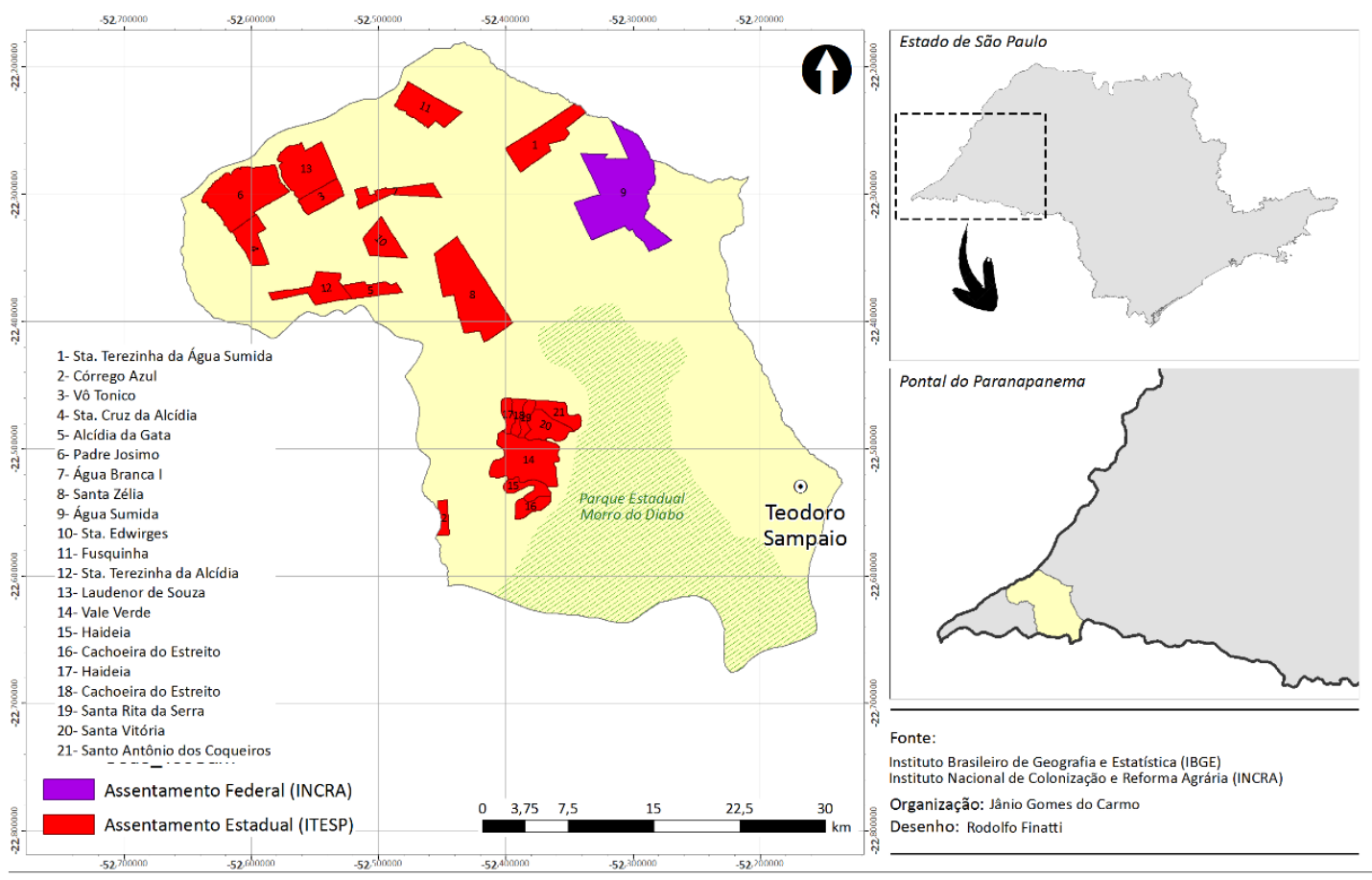

A responsabilidade da assistência técnica nos assentamentos dos municípios pesquisados é do Governo Federal, representado pelo INCRA e o Governo Estadual, por meio do ITESP. Estas instituições 
vêm, ao longo dos anos, trabalhando junto às famílias assentadas mediante a realização de ações favoráveis à uma política de assentamentos rurais e prestando assistência técnica aos produtores assentados, propiciando assim condições para o desenvolvimento das práticas agropecuárias, de acordo com Carmo e Brússolo (2015).

Quadro 1- Número de funcionários da Fundação ITESP nos municípios de Teodoro Sampaio e Caiuá

\begin{tabular}{|c|c|c|}
\hline Municípios & $\begin{array}{c}\text { Quadro de } \\
\text { Funcionários }\end{array}$ & Quantidade \\
\hline \multirow{4}{*}{ Teodoro Sampaio } & Técnico Agrícola & 10 \\
\cline { 2 - 3 } & Eng. Agrônomo & 4 \\
\cline { 2 - 3 } & Med. Veterinário & 4 \\
\cline { 2 - 3 } & $\begin{array}{c}\text { Funcionário do } \\
\text { Administrativo }\end{array}$ & 1 \\
\cline { 2 - 3 } & Zootecnista & 2 \\
\cline { 2 - 3 } & Assistente Social & 2 \\
\cline { 2 - 3 } & $\begin{array}{c}\text { Técnico de } \\
\text { Socioeconomia }\end{array}$ \\
\hline
\end{tabular}

\begin{tabular}{|c|c|c|}
\hline \multirow{4}{*}{ Caiuá } & Técnico Agrícola & 5 \\
\cline { 2 - 3 } & Eng. Agrônomo & 1 \\
\cline { 2 - 3 } & Med. Veterinário & 3 \\
\cline { 2 - 3 } & $\begin{array}{c}\text { Funcionário do } \\
\text { Administrativo }\end{array}$ & 3 \\
\cline { 2 - 3 } & Zootecnista & $*$ \\
\cline { 2 - 3 } & Assistente Social & 1 \\
\cline { 2 - 3 } & $\begin{array}{c}\text { Técnico de } \\
\text { Socioeconomia }\end{array}$ & 1 \\
\hline
\end{tabular}

Fonte: Fundação ITESP, 2014.

*Dados não informados.

Nos dois municípios estudados, o ITESP é o órgão responsável pela elaboração e implementação dos projetos para a obtenção de crédito agrícola para os assentados. Com esse apoio financeiro, eles iniciam suas atividades agropecuárias nas unidades produtivas com a montagem das infraestruturas necessárias e ainda recebem a assistência técnica oficial por meio de cursos de capacitação em diversas atividades agrícolas, buscando melhorar a rentabilidade dos lotes e também gerar emprego e renda. Deste modo, há um conjunto de profissionais que prestam assistência técnica nestes municípios do quadro do ITESP, conforme se verifica no Quadro 1.

A assistência técnica nos lotes é fundamental para que haja o desenvolvimento das atividades agropecuárias. Porém, o número de técnicos é insuficiente para atender a demanda dos assentados, o que, de certa forma, ajuda a explicar o baixo desenvolvimento da produção agropecuária realizada nos assentamentos, segundo Souza (2007).

A falta de assistência técnica de qualidade ofertada aos produtores assentados prejudica o desenvolvimento rural nos municípios, tendo em vista a dependência de tais sujeitos aos serviços oferecidos pela assistência oficial, sobretudo na elaboração e no desenvolvimento dos projetos, que necessitam de conhecimento técnico específico. No caso dos assentados rurais, poucos são aqueles que possuem e/ou têm acesso, devido ao seu baixo nível de instrução (escolaridade) ${ }^{1}$ e de recursos financeiros para pagar por estes serviços.

Nessa pesquisa foram entrevistados 17 assentados, entre presidentes de associações e vicepresidentes. Assim, averiguou-se que $88,23 \%$ (15 pessoas) afirmaram que são atendidos pela assistência oficial do ITESP e apenas $11,77 \%$ (dois produtores assentados) recebem assistência prestada por técnicos do INCRA, com a presença da assistência técnica do ITESP.

Entretanto, nota-se que a assistência técnica tem deixado lacunas. Segundo os relatos dos entrevistados, constatou-se três pontos importantes, tais como: 1) a falta de profissionais em número suficiente para atender a demanda nos lotes; 2) a demora no atendimento; e 3) a dificuldade de relacionamento dos produtores assentados com os técnicos. Isso tem redundado em alguns problemas, como:

1) a falta de assistência técnica adequada; 2) a necessidade de uma política agrícola mais eficiente; e 3) quantidade insuficiente de recursos financeiros disponibilizados. 
Segundo Verges (2011), os assentados precisam do apoio técnico para que possam ampliar a produção, entretanto, não é o que acontece nos assentamentos. A carência de assistência técnica regular prestada por engenheiros agrônomos, técnicos agrícolas, médicos veterinários, engenheiros ou técnicos florestais nos assentamentos rurais tem sido um entrave para os assentados.

Mesmo diante da presença da assistência técnica, os assentados rurais dos municípios pesquisados apresentam dificuldades nas práticas agrícolas. Certificou-se que o manejo inadequado dos recursos naturais tem provocado degradação ambiental, refletindo na baixa fertilidade dos solos nos dois municípios pesquisados, sendo que ambos apresentam pecuária mista de corte e leite de baixo padrão tecnológico, concentrados principalmente nas áreas dos assentamentos rurais.

Segundo Hespanhol (2010a, p. 8), a produtividade do rebanho é baixa, por causa do predomínio de gado misto, sobretudo a baixa qualidade do solo, que requer mais cuidados com a alimentação do gado, o que de fato não ocorre nos assentamentos, pois a quantidade "[...] de alimentos fornecidos aos animais é insuficiente, especialmente nos meses de inverno, quando normalmente os índices pluviométricos são menores", resultando no baixo rendimento dos assentados.

Os relatos do presidente da associação de produtores rurais do Assentamento Santa Zélia são elementos importantes, pois ele salienta alguns aspectos relacionados à baixa produção de leite realizada pelos produtores assentados ao longo dos anos no assentamento. Isso fica claro com os trechos da entrevista apresentado a seguir:

\footnotetext{
"Antes de nos instalarmos nesse assentamento, essa área era destinada ao gado de corte e não de gado leiteiro. Atualmente, orientados pelos técnicos do ITESP estamos trabalhando com o leite, mas a pastagem é a mesma utilizada pelo gado de corte, no passado. Dessa forma, dificilmente o gado vai produzir em grandes quantidades. Seria preciso investir no pasto, melhorar a qualidade do solo, fazer o uso de fertilizantes para corrigir a falta de fertilidade no solo, com isso melhoraria a produção e a renda"
}

Nessas áreas também são cultivadas lavouras para o autoconsumo, assim como o plantio de canade-açúcar para fornecer alimentos ao gado na época de estiagem, principal fonte de renda das famílias assentadas e dos demais pequenos produtores rurais de Caiuá e Teodoro Sampaio.

Os assentados rurais têm enfrentado as mesmas dificuldades dos demais pequenos produtores rurais, no que se refere à comercialização da produção e o acesso aos serviços de extensão rural, mesmo recebendo apoio dos técnicos do ITESP ${ }^{2}$, (HESPANHOL, 2010b).

Há de se destacar que, o direcionamento de políticas públicas oficiais para os assentados tem contribuído, mesmo com as muitas lacunas apresentadas, para a manutenção e permanência dessa população no espaço rural dos referidos municípios. Ainda assim, essa população encontra dificuldades de inserção da produção no mercado local, isso porque, na maioria das vezes, eles não conseguem atender as exigências sanitárias, regularidade na oferta e de padronização.

O PRONAF, ao longo dos mais de 20 anos de existência, por meio suas ações, tem procurado atender as realidades locais ao disponibilizar créditos com taxas de juros em condições de pagamento favoráveis aos beneficiários. Tanto é que, a partir de 1999, ao reorganizar sua estrutura, os gestores inseriram os assentados rurais nas normativas do Programa. Desde então, estes podem acessar os recursos ofertados, o que representa um avanço.

\section{O PROGRAMA NACIONAL DE FORTALECIMENTO DA AGRICULTURA FAMILIAR (PRONAF): MUDANÇAS E ADEQUAÇÕES}

O PRONAF, criado no ano de 1996, foi instituído com recursos do Fundo de Amparo ao Trabalhador (FAT). Contou ainda com a participação da operação do Ministério da Agricultura Pecuária e Abastecimento (MAPA) no direcionamento das ações. Para o levantamento das informações sobre seus beneficiários, tomou-se como base, o levantamento do Censo Agropecuário de 1995/96, bem como os estudos realizados pelo FAO/INCRA, o qual traçou o perfil social do agricultor familiar, que com base nesse levantamento projetou o montante de recursos disponibilizados para o público-alvo.

Ficou definido que: podem acessar os recursos do referido programa, aqueles que se enquadrarem nas especificações a seguir.

a) explorem parcela da terra na condição de proprietários, posseiros, arrendatários ou parceiros; b) mantenham até dois empregados permanentes, sendo admitido o recurso eventual a ajuda de terceiros, quando a natureza sazonal da atividade agropecuária $o$ exigir; c) não detenham a qualquer título, área superior a quatro módulos fiscais, quantificados na legislação em vigor; d) obtenham, no mínimo, $80 \%$ (oitenta por cento) de sua renda bruta anual da exploração agropecuária e/ou extrativa; e) residam na 
propriedade ou em aglomerado rural ou urbano próximo; f) possuam faturamento máximo anual até R\$ 27.500 reais (AQUINO, 2009, p. 6).

Ao longo dos anos foram realizadas alterações no formato do Programa, buscando diversificar os benefícios entre os beneficiários. Assim, em 1999 foram instituídos os grupos (A, B, C, D, E e A/C) ${ }^{3}$ para a obtenção de renda e enquadramento dos agricultores. As alterações buscaram aprimorar o apoio à infraestrutura, à renda e capacitação do público-alvo.

Em 2003, criou-se a Secretaria de Desenvolvimento Territorial (SDT), que buscou uma aproximação entre os agricultores familiares e as esferas administrativas do Governo, por meio da adoção do formato territorial como base para a implementação das políticas públicas. O governo procurou com esta mudança, estabelecer condições de crédito favoráveis para o desenvolvimento de práticas agrícolas pelos distintos grupos de agricultores familiares.

Para Ortega (2008), a Secretaria de Desenvolvimento Territorial (SDT) buscou estreitar os laços sociais entre os agricultores familiares e as instituições administrativas ao disponibilizar recursos para a tecnificação e capacitação dos sujeitos sociais, além de estimular o associativismo e a capitalização dos produtores agrícolas, sobretudo, o desenvolvimento de políticas públicas direcionadas para o território. Tais transformações possibilitaram um olhar mais atento para o rural visando combater a pobreza, a desigualdade social e econômica, alavancando assim o desenvolvimento rural.

Tal mudança propiciou uma nova segmentação do público-alvo do PRONAF, além de definir os critérios, as condições, os prazos e os juros a serem pagos pelos beneficiários na obtenção dos recursos financeiros acessados. Esta medida buscou adequar os recursos do programa à realidade social e produtiva de cada um deles, o que redundou na ampliação do acesso ao crédito. A medida representou um avanço, sobretudo para os assentados ${ }^{4}$ que foram contemplados na nova proposta. Esse grupo (grupos A e A/C) passou a ter acesso a recursos para investimentos nos lotes com taxas de juros baixas. Também foram criadas duas novas categorias de agricultores (D/E) ampliando as ações do PRONAF entre os agricultores mais capitalizados.

No Quadro 2, são apresentados os diferentes grupos de agricultores familiares que são beneficiários do PRONAF. 


\begin{tabular}{|c|c|c|}
\hline Grunes & M & Condiñ̃o \\
\hline $\mathbf{A}$ & $\begin{array}{l}\text { - Assentados da reforma agrária } \\
\text { e beneficiários do crédito } \\
\text { fundiário }\end{array}$ & $\begin{array}{l}\text { - Ser concessionário do Programa Nacional de } \\
\text { Fortalecimento da Reforma Agrária (PNRA). }\end{array}$ \\
\hline B & $\begin{array}{c}\text { Pescadores artesanais, } \\
\text { aquicultores; silvicultores, } \\
\text { extrativistas; integrantes de } \\
\text { comunidades quilombolas } \\
\text { rurais; povos indígenas; demais } \\
\text { povos e comunidades } \\
\text { tradicionais }\end{array}$ & $\begin{array}{l}\text { - Residir no estabelecimento ou em local próximo, } \\
\text { considerando as características geográficas regionais; } \\
\text { - Ser proprietário, posseiro, arrendatário ou parceiro; } \\
\text { não deter título de área superior a quatro módulos } \\
\text { fiscais; } \\
\text { - No mínimo } 50 \% \text { (cinquenta por cento) da renda bruta } \\
\text { familiar, seja originada da exploração agropecuária e } \\
\text { não agropecuária do estabelecimento; } \\
\text { - Tenham o trabalho familiar como predominante na } \\
\text { exploração do estabelecimento; } \\
\text { - Renda bruta familiar não superior a } 10.000 \text { reais e não } \\
\text { contratarem trabalho permanente; }\end{array}$ \\
\hline $\mathbf{A} / \mathbf{C}$ & $\begin{array}{l}\text { Assentados pelo Plano Nacional } \\
\text { de Reforma Agrária (PNRA) ou } \\
\text { beneficiários do Programa } \\
\text { Nacional de Crédito Fundiário } \\
\text { (PNCF) }\end{array}$ & $\begin{array}{l}\text { - Tenham contratado a primeira operação no Grupo } \\
\text { "A"; } \\
\text { - Não tenham contratado financiamento de custeio, } \\
\text { exceto no próprio Grupo "A/C"; mediante apresentação } \\
\text { de DAP válida. }\end{array}$ \\
\hline $\begin{array}{l}\text { Agricultores } \\
\text { Familiares } \\
\text { (AF) }\end{array}$ & $\begin{array}{c}\text { Pescadores artesanais, } \\
\text { aquicultores; silvicultores, } \\
\text { extrativistas; integrantes de } \\
\text { comunidades quilombolas } \\
\text { rurais; povos indígenas; demais } \\
\text { povos e comunidades } \\
\text { tradicionais }\end{array}$ & $\begin{array}{l}\text { - Que os agricultores residam no estabelecimento ou em } \\
\text { local próximo, considerando as características } \\
\text { geográficas regionais; } \\
\text { - Ser proprietário, posseiro, arrendatário ou parceiro; } \\
\text { - Não deter título de área superior a quatro módulos } \\
\text { fiscais; no mínimo } 50 \% \text { (cinquenta por cento) da renda } \\
\text { bruta familiar, seja originada da exploração } \\
\text { agropecuária e não agropecuária do estabelecimento; } \\
\text { tenham o trabalho familiar como base na exploração do } \\
\text { estabelecimento, podendo manter até dois empregados } \\
\text { permanentes; } \\
\text { - Tenham renda bruta anual dos últimos } 12 \text { meses de } \\
10.000 \text { reais mil até } 160.000 \text { reais; } \\
\text { - Incluída a renda proveniente de atividades } \\
\text { desenvolvidas no estabelecimento e fora dele, } \\
\text { excluídos os benefícios sociais e os proventos } \\
\text { previdenciários decorrentes de atividades rurais. }\end{array}$ \\
\hline
\end{tabular}

Fonte: Resolução 4.107 de 28/06/2012.

A operacionalização das ações pelos gestores do PRONAF buscou o enquadramento dos agricultores familiares por grupo, de maneira a propor ajustes financeiros às diferentes realidades, de modo a contemplar a forte heterogeneidade. Mas fica claro que, a medida adotada não favoreceu a distribuição igualitária dos recursos entre o público-alvo, pois, conforme os dados da Tabela 4, nota-se, a ampla disparidade entre os grupos beneficiados com os recursos do Programa ao longo dos anos. 
Tabela 4- Limite de renda do Plano Safra dos grupos de agricultores familiares e taxas de juros nas modalidades do PRONAF custeio e investimento (Em reais)

\begin{tabular}{|c|c|c|c|c|c|c|c|c|c|c|}
\hline \multicolumn{6}{|c|}{ Agricultores } & & \multicolumn{2}{|l|}{ Custeio } & \multicolumn{2}{|l|}{ Investimento } \\
\hline $\begin{array}{c}\text { Ano } \\
\text { Agrícola }\end{array}$ & $\begin{array}{c}\text { Grupo } \\
\text { A }\end{array}$ & $\begin{array}{c}\text { Grupo } \\
\text { B }\end{array}$ & $\begin{array}{c}\text { Grupo } \\
\text { C }\end{array}$ & $\begin{array}{c}\text { Grupo } \\
\text { D }\end{array}$ & $\begin{array}{c}\text { Grupo } \\
\mathbf{E}\end{array}$ & Grupo A/C & Limites & Juros a.a. & Limites & Juros a.a. \\
\hline 1999/00 & \multirow{14}{*}{$*$} & $1.500,00$ & $8.000,00$ & $27.750,00$ & Inexistente & \multirow[t]{14}{*}{$* *$} & $5.000,00$ & $5,75 \%$ & $15.000,00$ & $1 \%$ \\
\hline $2000 / 01$ & & $1.500,00$ & $8.000,00$ & $27.750,00$ & Inexistente & & $5.000,00$ & $5,75 \%$ & 15000,00 & $1 \%$ \\
\hline $2001 / 02$ & & $1.500,00$ & $80.000,00$ & $27.750,00$ & Inexistente & & $5.000,00$ & $4 \%$ & 15000,00 & 1 a $3 \%$ \\
\hline $2002 / 03$ & & $1.500,00$ & $10.000,00$ & $30.000,00$ & Inexistente & & $5.000,00$ & $4 \%$ & 15000,00 & 1 a $3 \%$ \\
\hline $2003 / 04$ & & $2.000,00$ & $14.000,00$ & $40.000,00$ & $60.000,00$ & & $6.000,00$ & 2 a $4 \%$ & 27000,00 & 1 a $7,25 \%$ \\
\hline $2004 / 05$ & & $2.000,00$ & $14.000,00$ & $40.000,00$ & $60.000,00$ & & $28.000,00$ & 2 a $4 \%$ & $54.000,00$ & 1 a $7,25 \%$ \\
\hline $2005 / 06$ & & $2.000,00$ & $14.000,00$ & $40.000,00$ & 60000,00 & & $28.000,00$ & 2 a $4 \%$ & $54.000,00$ & 1 a $7,25 \%$ \\
\hline 2006/07 & & $3.000,00$ & $16.000,00$ & $45.000,00$ & $80.000,00$ & & $28.000,00$ & 2 a $4 \%$ & $54.000,00$ & 1 a $7,25 \%$ \\
\hline $2007 / 08$ & & $4.000,00$ & $18.000,00$ & $60.000,00$ & $110.000,00$ & & $28.000,00$ & 1,5 a $3 \%$ & $54.000,00$ & 1 a $6,25 \%$ \\
\hline 2008/09 & & $5.000,00$ & \multirow{4}{*}{\multicolumn{3}{|c|}{$110.000,00$}} & & $30.000,00$ & $1,5 \%$ a $5,5 \%$ & $100.000,00$ & $0.5 \%$ a $5 \%$ \\
\hline $2009 / 10$ & & $6.000,00$ & & & & & $40.000,00$ & $1,5 \%$ a $5,5 \%$ & $100.000,00$ & $0,5 \%$ a $2 \%$ \\
\hline $2010 / 11$ & & $6.000,00$ & & & & & $50.000,00$ & $1,5 \%$ a $4,5 \%$ & $100.000,00$ & $0,5 \%$ a $2 \%$ \\
\hline 2011/12 & & $6.000,00$ & & & & & $50.000,00$ & $1,5 \%$ a $5,5 \%$ & $130.000,00$ & $0,5 \%$ a $2 \%$ \\
\hline $2012 / 13$ & & $10.000,00$ & & $160.000,00$ & & & $80.000,00$ & $1,5 \%$ a $4 \%$ & $130.000,00$ & $0,5 \%$ a $2 \%$ \\
\hline
\end{tabular}

Fonte: Plano Safra, 2012/2013

* Agricultores familiares assentados pelo Plano Nacional de Reforma Agrária (PNRA) com o primeiro crédito para estruturação dos lotes. Os valores recebidos pelo grupo podem chegar até 20.000 reais com juros de 0,5 a.a. Esses recursos são direcionados para a implantação de infraestrutura nos lotes.

** Recebido o primeiro crédito, esse grupo pode adquirir investimentos para o custeio dos lotes de 5.000 reais com juros de 1,5\% a.a. Ver Plano Safra (2012/13). 
Todavia, as normativas do Programa evidenciam o "privilégio" dos recursos para os agricultores familiares dos grupos C, D e E, por apresentarem mais facilidades para se enquadrarem nas modalidades de financiamento e custeio. Sendo assim, as condições de crédito para esses grupos variam conforme a renda bruta anual com condições de empréstimos e taxas de juros ${ }^{5}$ anuais favoráveis, possibilitando melhorias na produção e, consequentemente, podendo ser mais rentável e lucrativa, do que os agricultores mais pauperizados, os quais apresentam dificuldades para acessar os recursos do Programa.

A forma de liberação dos recursos pelos agentes financeiros, que preferem atender aos agricultores já estabilizados por apresentarem garantias de pagamento dos financiamentos, está na base desse forte direcionamento do crédito ao grupo já mais capitalizado. Assim, os agricultores menos capitalizados (grupos A e A/C), aqueles que realmente necessitam dos recursos públicos não encontram as mesmas facilidades de financiamentos que os demais grupos, consequentemente, os benefícios concentramse entre os agricultores dos grupos $\mathrm{C}, \mathrm{D}$ e $\mathrm{E}$.

A medida $\operatorname{adotada}^{6}$ (disponibilização de créditos) não atende as expectativas dos assentados rurais devido à reduzida quantidade de recursos ofertada entre os agricultores familiares, em consequência de não conseguirem oferecer as garantias exigidas pelas instituições financeiras.

Um dos grandes entraves desse grupo consiste em declarar uma renda ${ }^{7}$, tendo em vista a sazonalidade nos preços e custos dos produtos agrícolas, assim como a dificuldade de computar a renda indireta obtida por meio dos produtos utilizados no autoconsumo, os quais não são considerados na composição da renda bruta familiar.

Ademais, ao mesmo tempo em que os critérios estabelecidos pelos gestores do Programa reconhecem a diversidade socioeconômica da agricultura familiar, contudo, uma parcela considerável de agricultores familiares menos favorecidos apresentava dificuldades para serem contemplados com os recursos financeiros dessa política pública - o PRONAF, por exemplo, os assentados rurais.

Dessa forma, ao longo dos anos, o Programa tem alterado sua estrutura, bem como sua concepção, gestão e organização, fazendo com que suas ações passassem a ser consideradas inovadoras, pelo fato de buscar ampliar o número de beneficiários. Todavia, considera-se essas mudanças como um divisor de águas, pelo fato de atender com políticas públicas específicas os agricultores familiares, fortalecendo o vínculo deles com o desenvolvimento das práticas agrícolas, aumentando a capacidade produtiva, além de prover com recursos a realização de melhorias na capacidade técnica e contribuir com a geração de emprego e renda no espaço rural. 
Quadro 3- Enquadramento e condições dos beneficiários do PRONAF

\begin{tabular}{|c|c|c|c|}
\hline \multicolumn{4}{|c|}{ Custeio } \\
\hline Grupos & Limites de Crédito & Juros & Prazos \\
\hline Grupo A/C & Até 7.500 reais & $1,5 \%$ & $\begin{array}{l}\text { I - custeio agrícola: até } 2 \text { (dois) anos, observado o ciclo de cada } \\
\text { empreendimento; } \\
\text { II - custeio pecuário: até } 1 \text { (um) ano; } \\
\text { III - custeio para agroindústria: até } 1 \text { (um) ano. }\end{array}$ \\
\hline \multirow{3}{*}{$\mathbf{A F} / \mathbf{B}$} & Até 10.000 reais & $1,5 \%$ & \multirow{4}{*}{$\begin{array}{l}\text { Custeio agrícola até um ano, exceto: } \\
\text { I - açafrão e palmeira real (palmito) até } 3 \text { (três) anos; } \\
\text { II - culturas bianuais até } 2 \text { (dois) anos; } \\
\text { Custeio pecuário: } \\
\text { I - para aquicultura: até } 2 \text { (dois) anos, conforme o ciclo produtivo de cada } \\
\text { espécie contido no plano, proposta ou projeto; } \\
\text { II - para as demais atividades: até } 1 \text { (um) ano. } \\
12 \text { meses. }\end{array}$} \\
\hline & Acima de 10.000 reais até 30.000 reais & $2 \%$ a.a. & \\
\hline & Acima de 30.000 reais até 100.000 reais & $3,5 \%$ a.a. & \\
\hline Cooperativas & $\begin{array}{l}\text { Até } 30 \text { milhões (cooperativas Centrais) } \\
10 \text { milhões (cooperativas singulares) não } \\
\text { ultrapassando limite de } 12.000 \text { reais por } \\
\text { cooperado. }\end{array}$ & $4 \%$ a.a. & \\
\hline \multicolumn{4}{|c|}{ Investimento } \\
\hline Grupo A & $\begin{array}{l}25.000 \text { reais (podendo chegar a } 26.500 \text { reais } \\
\text { com ATER) }\end{array}$ & $0,5 \%$ a.a. & Até dez anos \\
\hline Grupo B & $\begin{array}{l}\text { Até } 4.500 \text { reais com metodologia do } \\
\text { PNMPO e } 2.500 \text { reais sem metodologia }\end{array}$ & $0,5 \%$ a.a. & 2 anos \\
\hline \multirow{2}{*}{$\begin{array}{l}\text { AF mais alimento } \\
\text { AF }\end{array}$} & Até 10.000 reais & $1 \%$ a.a. & \multirow[b]{2}{*}{ Até dez anos } \\
\hline & $\begin{array}{l}\text { Entre } 10.000 \text { reais e } 150.000 \text { reais (podendo } \\
\text { chegar a } 300.000 \text { reais quando se tratar de } \\
\text { suinocultura e avicultura) }\end{array}$ & $2 \%$ a. a. & \\
\hline Pronaf Agroindústria & $\begin{array}{l}\text {-Pessoa física: até } 150.000 \text { reais- } \\
\text { Empreendimento familiar rural }- \text { pessoa } \\
\text { jurídica: até } 300.000 \text { reais -Cooperativa até } \\
35.000 \text { reais observado o limite individual } \\
\text { de } 45.000 \text { reais cooperado. }\end{array}$ & $\begin{array}{l}1 \% \text { a.a. para financiamentos de } \\
\text { até } 1 \text { milhão limitados a } 10 \\
\text { milhões por cooperado. } \\
2 \% \text { a. a. demais situações. }\end{array}$ & Até dez anos e quinze anos quando se tratar de obras de armazenagem. \\
\hline
\end{tabular}

Fonte: Manual do Crédito Rural (MCR) 2014/2015.

* PRONAF custeio para a Reforma Agrária.

** PRONAF investimento para a Reforma Agrária. 
As mudanças nessa política pública propiciaram um aumento no montante de recursos destinados aos distintos grupos de agricultores familiares beneficiados, conforme evidenciado no Quadro 3, por meio do enquadramento e condições estabelecidas pelo Manual do Crédito Rural (MCR) (2014/2015).

Todavia, mesmo diante desse crescimento expressivo em relação à quantidade de recursos financeiros disponibilizados, que ocorreu devido às baixíssimas taxas de juros cobradas dos beneficiados, ainda é possível notar a discrepância na quantidade de recursos ofertados ao público-alvo (sobretudo, aos assentados). Nota-se que, as operações financeiras com os maiores valores continuam sendo direcionadas para os agricultores familiares já capitalizados, que conseguem atender às normas dos agentes financeiros, por exemplo, o grupo de "agricultores familiares" (AF). O mesmo, não atendeu com o mesmo volume de recursos e demandas dos grupos menos expressivos (A, B e A/C), os quais detêm a maioria dos estabelecimentos rurais, porém, as menores condições de acesso aos benefícios financeiros, levando em conta o novo formato com linhas de créditos específicas para os diferentes grupos de agricultores familiares.

A operacionalização das ações pelos gestores do PRONAF tem privilegiado os segmentos familiares que já se encontram em melhores condições socioeconômicas, com recursos e condições privilegiadas de crédito. Isso fica claro com a afirmação a seguir: "[...] a própria criação dos grupos do PRONAF resultou do reconhecimento da diversidade no interior da agricultura familiar e da necessidade de tratá-la de acordo com suas especificidades" (GRISA; WESZ JUNIOR; BUCHWEITZ, 2014, p. 233).

Para Mattei (2011), as inovações que foram introduzidas ao longo dos anos de existência do PRONAF não resultaram numa política que efetivamente atenda a todos os segmentos ligados à agricultura familiar. O que tem ocorrido é a reprodução nas características do público beneficiário e a dependência de trajetória e seletividade observada pela adoção do crédito rural tradicional.

No mesmo sentido, as mudanças no enfoque das políticas públicas com a implantação do PRONAF têm apresentado problemas quanto à oferta de crédito rural, pelo fato de as ações privilegiarem os grupos de agricultores familiares já capitalizados e integrados ao mercado. Isso faz com que os agricultores familiares que se encontram em condições vulneráveis tenham cada vez menos espaço para participar do mercado, por não apresentarem as mesmas condições de produção e de acesso a financiamentos (HESPANHOL, 2008).

O caráter produtivista do PRONAF confirma a seletividade dos benefícios deste Programa em termos de produtos e de grupos de agricultores familiares, conforme demonstram os trabalhos de Aquino (2009), Guanzirolli (2007), Grisa, Wesz Junior e Buchweitz (2014) e Niederle (2014).

Apesar de o PRONAF ser uma política pública diferenciada no que tange ao seu público-alvo, suas ações têm sido delineadas com um enfoque produtivista e setorial, segundo envidenciam os trabalhos de Aquino (2009) e Niederle (2014).

Portanto, são necessários avanços operacionais na estrutura do PRONAF, assim como nas instituições fomentadoras deste benefício. Segundo Hespanhol (2008), mesmo com as mudanças institucionais, operacionais, ainda persiste o desafio na geração de renda entre os agricultores familiares e, não há indicações claras de que tais desafios serão superados a curto e médio prazo.

Isso fica nítido quando analisamos os aspectos relacionados aos grupos de assentados dos municípios de Teodoro Sampaio e Caiuá. Nota-se que, os recursos ofertados para os assentados por esta política não atendem com o mesmo montante acessado pelos produtores rurais mais capitalizados, ou seja, aqueles que realmente necessitam dos recursos para o desenvolvimento das práticas agrícolas no meio rural, pois apresentam dificuldades para acessar os recursos do Programa.

\section{OS RECURSOS DO PRONAF PARA AS CATEGORIAS A E A/C: GRUPOS DE ASSENTADOS DA REFORMA AGRÁRIA NOS MUNICÍPIOS DE TEODORO SAMPAIO E CAIUÁ - SP}

A partir de 2003, o Governo Lula começou a colocar em prática, parte das promessas realizadas durante a campanha eleitoral, que consistia no combate e erradicação da pobreza. Um caminho escolhido para isso foi investir na agricultura familiar. Desde então, o PRONAF tem alterado os critérios para o acesso ao crédito rural subsidiado, buscando maior equiparidade nas ações entre os distintos grupos de agricultores.

Sendo assim, as alterações feitas pelos gestores do PRONAF se prolongaram, tanto é que, em $2008^{8}$, o governo promoveu uma alteração nos grupos de beneficiários, além de estipular as variações nas taxas de juros, conforme o enquadramento por renda, propiciando mais facilidades no pagamento dos benefícios do Programa. Buscava-se com essa medida, mais equidade na distribuição dos recursos do Programa, sobretudo, ampliar a abrangência entre os diversos grupos de agricultores familiares beneficiados.

Acreditava-se que, com a reformulação dos critérios para a obtenção de recursos do Programa, bem como o aumento no volume de recursos e a sua espacialização, os grupos menos capitalizados e em condições mais vulneráveis sob o ponto de vista socioeconômico, dentre eles os assentados, conseguiriam 
acessar um montante maior de recursos, dada a maior facilidade nas condições de pagamento para este grupo.

Todavia, as medidas adotadas ampliaram significativamente o volume de recursos e o número de contratos direcionados para os distintos grupos de beneficiários do PRONAF. Entretanto, a capitalização não ocorreu entre os distintos segmentos sociais, pois os grupos de agricultores familiares já capitalizados foram privilegiados com as alterações, por apresentarem maior valor de renda bruta anual e se encontrarem mais estruturados em termos econômicos e produtivos.

Para Mattei (2014), a parcela de agricultores com baixa renda continua apresentando dificuldades em obter os recursos monetários, principalmente entre os grupos A e A/C. Segundo Souza et al. (2013), a não equidade na distribuição dos recursos do referido Programa contribui com o crescimento da desigualdade social entre os tipos de agricultores.

Mesmo com essas garantias, ao longo dos anos, constata-se o baixo volume de recursos acessados pelos assentados. Trata-se de uma parcela expressiva de famílias assentadas localizadas em áreas vulneráveis do país que precisa de apoio oficial para permanecerem se reproduzindo em condições dignas na zona rural.

O PRONAF aparece em cena, principalmente nessas áreas de assentamentos, como um instrumento capaz de modificar as possibilidades destes sujeitos sociais, por meio do direcionamento de recursos financeiros, seja na forma de investimentos ou até mesmo no custeio das atividades agrícolas. Suas ações visam melhorar a condição de vida dos assentados ${ }^{9}$, por meio da geração de renda.

Nessa perspectiva, tivemos parcelas consideráveis de assentados nos municípios pesquisados que adquiriram recursos do Programa, os quais foram investidos na implantação de benfeitorias nos lotes, por exemplo, conserto de cercas, construção de currais, compra de gado, vacinas e medicamentos animal. Os assentados usam os recursos para a manutenção dos lotes, bem como sua sobrevivência nos espaços rurais pesquisados.

Os recursos acessados visam, principalmente, a modalidade de custeio das atividades agrícolas, utilizados basicamente para o cultivo de feijão, lavouras, milho, mandioca, hortaliças entre outros, possibilitando melhorias para o autoconsumo destes produtos e na geração de renda, mediante a comercialização do seu excedente. Também estabelece investimento para a realização de infraestrutura, propiciando a aquisição de equipamentos agrícolas (enxada, foice, triturador, enxadão, limas, dentre outros), compra de adubo, calcário para melhoramento do solo e da produção. Estas ações têm contribuído com a melhora no desenvolvimento das atividades agrícolas desenvolvidas no espaço rural pesquisado de acordo com o que constatamos na Pesquisa de Campo, 2014.

A modalidade de custeio das atividades agrícolas, tem possibilitado o acesso a recursos para a aquisição de adubos, sementes, que são utilizados para o cultivo de produtos de gêneros de primeira necessidade, por exemplo, milho, mandioca e alguns produtos olerícolas, segundo a Pesquisa de Campo efetuada em 2014.

Nos assentamentos rurais a produção agrícola se destina ao autoconsumo e à comercialização pelas famílias. São direcionadas para o autoconsumo dos produtos de primeira necessidade (milho, feijão, arroz, mandioca), ocorrendo uma economia de recursos porque com o cultivo destes produtos evita-se a sua compra nos supermercados, segundo Leal (2003).

Entre os entrevistados, 17 pessoas (100\%) alegaram ter recebido o crédito rural, todavia, há relatos de produtores assentados que ainda não conseguiram obter acesso ao crédito rural. Segundo eles, os motivos são: a inadimplência ou pelo fato de o assentamento ter sido contemplado recentemente, como o caso do assentamento Nossa Senhora das Graças em Caiuá. Dentre os entrevistados que declararam ter recebido recursos, cinco pessoas $(29,31 \%)$ são do município de Caiuá, enquanto que 12 pessoas $(70,59 \%)$ são de Teodoro Sampaio. Constatou-se que, os recursos acessados foram investidos na montagem de infraestrutura, com a aquisição da matriz leiteira (vacas, montagem do cercado para os animais) propiciando assim condições para o desenvolvimento das atividades agrícolas, bem como o início das primeiras atividades agropecuárias realizadas nos lotes.

O crédito agrícola torna possível a formação e o desenvolvimento das atividades agropecuárias nos lotes. As primeiras atividades agrícolas no lote ocorrem com a preparação do solo para o cultivo de hortaliças, plantio de mandioca, milho, leguminosas entre outros produtos, isto é, a montagem de pequenas lavouras.Há de se destacar também o desenvolvimento da pecuária leiteira, que oferece liquidez mensal regular à família assentada. A prática da pecuária acontece com a aquisição das primeiras cabeças de gado, importante para a sobrevivência e a permanência das famílias assentadas no espaço rural, pois é com o desenvolvimento dessas atividades que adquirem a renda para o sustento familiar. Todavia, o volume de recursos acessados pelos assentados rurais ainda é baixo e as novas regras implantadas, devido às alterações no Programa, têm prejudicado os assentados, pois, na maioria das vezes, eles não conseguem acompanhar tais mudanças, dadas às exigências burocráticas para a obtenção dos recursos, o que os desestimula a contraírem novos financiamentos, mesmo com baixas taxas de juros. 
A produção realizada nos assentamentos, normalmente é em baixa escala, devido ao tamanho dos lotes, bem como pelas dificuldades encontradas pelos assentados em obter recursos para o desenvolvimento das práticas agrícolas nas unidades produtivas. Sendo assim, consideramos somente as culturas mais representativas.

A Figura 1 mostra de forma contundente as principais práticas agrícolas realizadas em alguns dos assentamentos rurais dos municípios de Teodoro Sampaio e Caiuá. Nota-se que, o lote apresenta uma considerável diversidade produtiva.

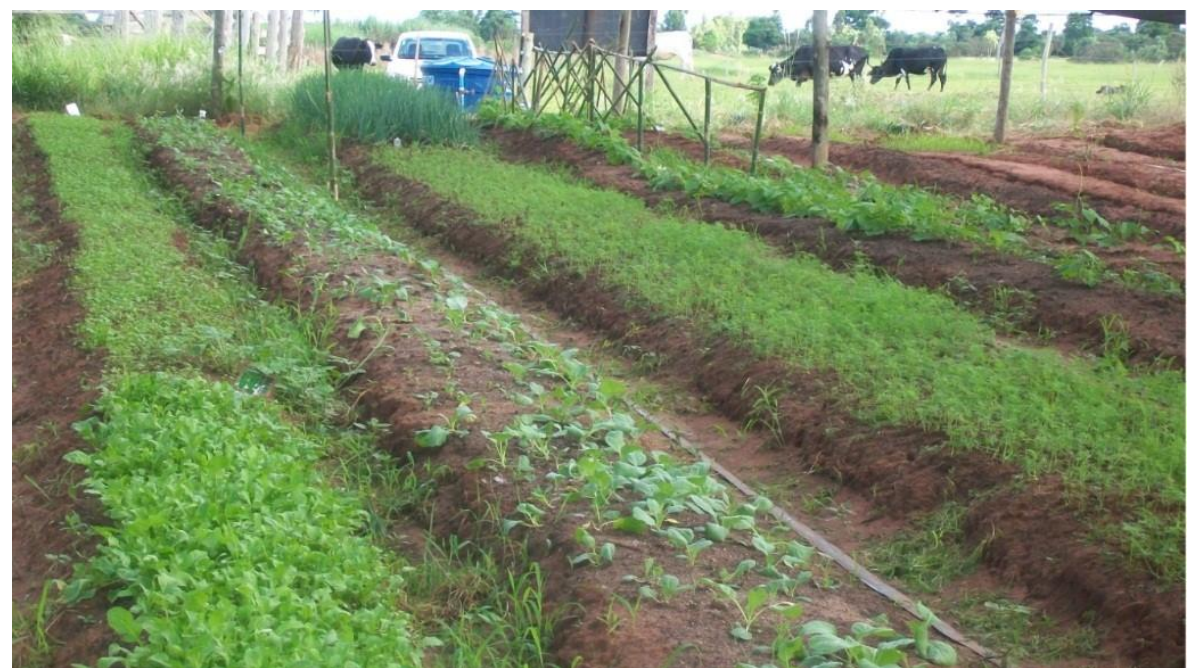

Figura 1- Produção de hortaliças e criação de gado, Assentamento Laudenor de Souza, Teodoro Sampaio. Fonte: Pesquisa de campo, 2014.

Quatro entrevistados alegaram ter contratado financiamento de custeio, utilizado para fazer pequenas reformas na pastagem, compra de adubo e de semente para o cultivo das atividades agrícolas. Dentre os produtores assentados entrevistados, oito declararam que enfrentam dificuldades para acessar o financiamento de custeio do PRONAF. Constatamos que as dívidas contraídas nas agências bancárias no passado não foram liquidadas, deixando-os inadimplentes, o que impossibilita o acesso deles a novos financiamentos do Programa. Já cinco produtores assentados declararam que, naquele momento, não tinham interesse na obtenção de novos financiamentos, quando indagados sobre os motivos, alegaram dificuldades para sua obtenção - problemas com financiamentos anteriores, inadimplência, e principalmente as incertezas no desenvolvimento das atividades agropecuárias.

Todavia, isso repercute na dinâmica das ações do Programa, tanto é que, a modalidade custeio apresentou baixa adesão entre os assentados, pois eles não conseguem apresentar as condições exigidas pelas agências bancárias para solicitar os recursos. Soma-se a isso ainda os riscos que a produção agrícola pode sofrer com as intempéries naturais, bem como as oscilações dos preços dos produtos no mercado.

As atividades agropecuárias são de extrema importância para os assentados rurais, porém, eles enfrentam dificuldades na obtenção dos benefícios oriundos das políticas públicas governamentais, que de certa forma acaba por interferir na realização da produção no interior dos lotes, contribuindo para a baixa geração de emprego e renda a tais sujeitos, pois é via recursos públicos que os produtores assentados têm a possibilidade de realizar o desenvolvimento das atividades agropecuárias, viabilizando a inserção dos produtos no mercado.

Outro aspecto importante se trata da presença de instituições financeiras nos municípios onde se encontram implantados os assentamentos rurais. A falta de agências bancárias contribui também para o baixo acesso aos recursos subsidiados pelo PRONAF, pois é preciso que os assentados rurais se desloquem até as agências mais próximas, muitas vezes localizadas em outros municípios. O exemplo do município de Caiuá é notório, pois nesta cidade não tem uma agência do Banco do Brasil. Já em Teodoro Sampaio, há uma agência, o que facilita a solicitação de recursos pelos assentados rurais.

Outro problema é a falta de informações sobre os procedimentos necessários para a solicitação dos recursos, haja vista que, as instituições financeiras exigem alguns documentos para liberar o dinheiro. Nota-se que, muitos assentados entrevistados não sabem quais são os documentos ou têm dificuldades para apresentá-los, tais como: a certidão de casamento; célula de identidade; cadastro de pessoa física (CPF); comprovação de agricultor e sua condição como proprietário, arrendatário, meeiro, entre outros. Estes 
foram alguns dos problemas constatados durante as entrevistas. É sabido que a falta da documentação comprobatória é um empecilho para obtenção dos recursos do PRONAF.

A falta de orientação e esclarecimento constitui um grande problema para os beneficiários do PRONAF em realizar as operações financeiras, pois o desconhecimento da documentação exigida decorre da pouca informação obtida pelos beneficiários, principalmente pelo baixo nível de escolaridade apresentado, por exemplo, carta de anuência quando não se tem o título da propriedade, Declaração de Aptidão ao Pronaf (DAP), tornando-se um empecilho para a obtenção de recursos financeiros (VELOSO, 2011), que consequentemente desmotiva os interessados em solicitar o crédito rural e assim tende a inviabilizar a produção ou melhorias e incremento na estrutura produtiva dos lotes.

No tocante às políticas públicas, é sabido que a presença dos assentados rurais em áreas reformadas requer mais atenção das autoridades públicas, pois essas famílias ao adentrarem no lote, em geral, apresentam exíguos recursos e significativas demandas, que vão desde infraestrutura para moradia, como para a produção propriamente dita, que neste caso, tais necessidades só podem ser supridas com a garantia do acesso às distintas políticas públicas.

Todavia, as políticas públicas são executadas e geridas pelo Estado. Nesse processo, ganha importância a participação social reivindicando melhores condições em infraestrutura, para o desenvolvimento das práticas agrícolas, esse é um passo importante para melhorar a condição de vida das famílias assentadas.

Com esse mecanismo de intervenção, o Estado procura regular o mercado agrícola, ao mesmo tempo em que estimula a renda e garante preços aos produtos da agricultura familiar. Assim, torna-se importante o estabelecimento de linhas de crédito para o desenvolvimento e o financiamento das atividades agrícolas, a exemplo do PRONAF (LEAL, 2003).

Diante do exposto, fica clara a dificuldade no enquadramento das alterações nas normas do PRONAF pelos assentados da reforma agrária, em especial o aumento na renda bruta anual, usada como enquadramento das categorias do público-alvo. Para Aquino (2009), o atual desenho normativo do PRONAF continua privilegiando o crescimento das atividades ligadas ao agronegócio. Assim, a política de crédito não vem contribuindo para diminuir a desigualdade social e as assimetrias no interior da agricultura familiar, pelo contrário, vem até aprofundando-as.

\section{CONSIDERAÇÕES FINAIS}

O espaço rural dos municípios analisados é marcado pela forte concentração fundiária. A partir dos anos 1990, começou a luta pela realização da reforma agrária que culminou com a implantação dos assentamentos rurais em alguns municípios do Pontal, inclusive em Caiuá e Teodoro Sampaio.

A implantação de assentamentos rurais foi importante para a revitalização demográfica da área rural dos dois municípios estudados, pois favoreceu o dinamismo econômico e a geração de renda.

Constatou-se que os lotes apresentam baixa produção agrícola, dependente da atividade leiteira, que também é de baixa produtividade devido ao baixo nível em infraestrutura apresentada pelas unidades produtivas, baixo nível de inversão, preços baixos recebidos pelo leite, sendo recorrente a falta de nutrientes no solo e recursos para melhorar as pastagens.

Houve pequenos avanços no PRONAF: acesso aos financiamentos pelos produtores assentados; aumento nos limites de financiamento do crédito agrícola; possibilidade da montagem da estrutura agrícola, os quais tem possibilitado aos sujeitos iniciarem às primeiras atividades geradoras de renda nas unidades produtivas, possibilitando ocupação e renda às famílias assentadas.

Entretanto, esse grupo tem apresentado dificuldades para obter os financiamentos do Programa devido a pouca infraestrutura disponível e da baixa renda obtida, por sua vez, a falta de incentivo contribui com o baixo desenvolvimento da produção agropecuária e, por conseguinte, da geração de emprego e renda.

Importante destacar, que a oferta de crédito subsidiado é insuficiente para alavancar a produção nos lotes. É fundamental a existência de uma assistência técnica que vá além do âmbito estritamente técnico e envolva também orientações para a administração interna do lote e a sua relação com o mercado, pois dependendo do produto agrícola produzido e a época do ano, os preços obtidos com a venda no mercado, sequer cobrem os custos de produção. Isso desencoraja os assentados a efetuarem novos investimentos na estrutura produtiva interna dos lotes. O crédito rural, que deveria ser uma saída para alavancar as populações rurais mais vulneráveis, se torna uma barreira para os grupos instalados em áreas de baixo desenvolvimento social e econômico, pois, tais grupos não conseguem ter os mesmos privilégios do que os agricultores familiares já capitalizados, devido ao fato de não conseguirem apresentar as garantias exigidas pelas instituições financeiras em detrimento de uma série de problemas, a exemplo, a baixa renda adquirida com os produtos agropecuários. Assim, a atuação do PRONAF, mesmo com os avanços ocorridos, ainda não tem sido suficiente para atender os grupos mais vulneráveis socialmente e menos capitalizados. 
É necessário a implementação de políticas públicas para além da oferta de crédito, de diferentes tipos e em distintas esferas para atender aos assentados, como educação, saúde, assistência técnica, cursos e treinamentos, geração de condições para acesso ao mercado em condições satisfatórias, dentre outras.

\section{NOTAS}

1 - Os assentados rurais entrevistados apresentaram faixa etária de 30 a 61 anos. Nesse grupo, constatamos, por meio das entrevistas realizadas, que o nível de escolaridade é baixo, pois $23,53 \%$ dos entrevistados apresentavam ensino fundamental incompleto ( $1^{\mathrm{a}} \mathrm{a} 4^{\mathrm{a}}$ série), sendo duas pessoas em cada município. Quanto aos moradores dos assentamentos que completaram o ensino fundamental, identificamos $41,17 \%$. Verificou-se que entre o grupo de assentados que concluiu o ensino fundamental e aqueles não concluintes perfazem $62 \%$ dos entrevistados. Entre aqueles que concluíram o ensino médio, somavam-se seis pessoas, ou seja, $35,29 \%$.

2 - Apesar de estar presente em várias regiões do território paulista, o ITESP enfrenta alguns problemas estruturais quanto ao oferecimento de serviços de qualidade nos lotes, que de certa forma, afetam a orientação prestada aos assentados, pois seu quadro de profissionais é baixo e a falta de estrutura tem prejudicado o desenvolvimento das ações de assistência técnica nos municípios de Teodoro Sampaio e Caiuá, presentes nessa pesquisa.

3 - No ano de 1994 foram apresentados os critérios pelo FAO/INCRA para a definição dos agricultores familiares e a classificação dos estabelecimentos rurais, com isso, insistiu-se na separação entre agricultores patronais e agricultores familiares, identificadas por Scheneider; Cazzela e Mattei (2004). Com base nas Resoluções 2.629 de 1999 e a de $\mathrm{n}^{\circ} 3.206$ de 2004, tínhamos os seguintes grupos de beneficiários e os respectivos benefícios do PRONAF (A, B, C, A/C, D e E). Grupo A - agricultores assentados da reforma agrária, podendo financiar até 2.500 reais (custeio da safra) juros de $2 \%$ ao ano e até 13.500 reais (investimentos) juros de 1,5\% ao ano. Grupo B - agricultores familiares, remanescentes de quilombos, trabalhadores rurais e indígenas, podendo financiar até 1.000 reais entre custeio mais investimentos, juros de $1 \%$ ao ano. Grupo C - grupo familiar com renda bruta anual variando de 2.000 reais a 14.000 reais, podendo financiar até 2.500 reais (custeio da safra) com juros de $4 \%$ ao ano e até 5.000 reais (investimentos) com a mesma taxa de juros. Grupo D - agricultores estabilizados economicamente, cuja renda bruta familiar anual esteja entre 14.000 reais e 40.000 reais, podendo financiar até 6.000 reais (custeio da safra) com juros de $4 \%$ ao ano e até 18.000 reais (investimentos) com juros de $4 \%$, com descontos de $25 \%$ com o pagamento no prazo. Grupo E - agricultores com renda bruta anual esteja entre 40.000 reais e 60.000 reais (mas que de certa forma se enquadra nos critérios da agricultura familiar), podendo financiar até 28 mil (custeio da safra) e até 36.000 reais (investimentos) ambas as modalidades com juros de 7,5\% ao ano. Grupo A/C - assentados da reforma agrária e que passam a receber o primeiro crédito de custeio após terem obtido o crédito de investimento inicial que substituiu o antigo programa de apoio aos assentados podendo financiar de 500 reais até 2.500 reais (custeio da safra) juros de $2 \%$ ao ano, segundo Mattei (2007).

4 - O MDA tem se incumbido da condução política de assentamentos rurais, inadequadamente cognominada de reforma agrária e do PRONAF. As metas quantitativas e qualitativas estabelecidas para os assentamentos não têm sido atingidas. O programa, por sua vez, permanece estritamente vinculado à oferta de crédito rural com subvenções diferenciadas de acordo com a dimensão e o perfil dos beneficiários, ou seja, restringe ao oferecimento de crédito (HESPANHOL, 2008, p. 84).

5 - Nota-se que a taxa de juros vem diminuindo gradativamente. Os juros cobrados pelas agências de fomento variavam de $1 \%$ a 7,25\% no período de 1999 a 2003. A partir dessa data, temos uma redução de 3,25\% nos juros cobrados, ficando entre $0,5 \%$ a $4 \%$ a.a. no Plano Safra 2012/13, conforme a modalidade do PRONAF.

6 - Carneiro (1997) já alertava a maneira desproporcional estabelecida pelos critérios de seleção dos beneficiários do PRONAF. A autora salienta que, 2,3 milhões de estabelecimentos, aproximadamente 11 milhões de agricultores familiares encontravam-se marginalizados, não podendo requerer os benefícios por estarem excluídos, pelo fato de as ações contemplarem, somente, os agricultores com capacidade empresarial, portanto, propensos ao desenvolvimento das atividades agrícolas, marginalizando aqueles mais pauperizados.

7 - Para Graziano da Silva e De Grossi (2000), a renda da produção da agricultura familiar é subdeclarada, pois existe a dificuldade em estimar o valor mensal da renda dos produtos sazonais, observa-se ainda que, parte dessa renda compõe a produção autoconsumida pelos agricultores.

8 - A Resolução 3.559 de 28/ 03/ 2008 extinguiu os dos grupos C, D e E, permanecendo, somente os grupos A, C e A/C. Os beneficiários dos grupos extintos foram enquadrados num único grupo, Agricultores Familiares (AF).

9 - No que se refere ao Manual do Crédito Rural 2014/15, o Grupo A (assentados da reforma agrária e beneficiários do crédito fundiário) com os novos critérios estabelecidos, direcionou volume de recursos com financiamentos e investimentos de até $25.000,00$ reais, com taxas de juros de 0,5\% a.a. e prazo de dez anos para pagar. O grupo A/C é composto por aqueles assentados pelo PNRA ou beneficiários do Programa Nacional de Crédito Fundiário - (PNCF), que já contrataram a primeira operação no grupo A e não tinham realizado financiamento de custeio, exceto no próprio grupo A/C, cuja Declaração de Aptidão ao Pronaf - (DAP) não esteja bloqueada, tem o direito em crédito de custeio de até $7.500,00$ reais, com taxas de juros de 1,5\% a.a. com prazos variando de 1 a 2 anos para saldar o financiamento. 


\section{REFERÊNCIAS}

AQUINO, J. R. (2009). Avanços e limites da política de crédito do PRONAF no Brasil (1996-2008): uma reflexão crítica. Porto Alegre: CONGRESSO DA SOCIEDADE BRASILEIRA DE ECONOMIA E SOCIOLOGIA RURAL (SOBER), XLVII.

CARMO, J. G. (2015). O PRONAF nos municípios de Caiuá e Teodoro Sampaio - SP. Presidente Prudente. FCT-UNESP (Dissertação, mestrado em Geografia Agrária).

CARMO, J. G.; BRÚSSOLO, R. G. (2015). Análise dos efeitos socioterritoriais do assentamento rural água sumida no município de Teodoro Sampaio/SP. São Gonçalo: Revista Tamoios

CARNEIRO, M. J.; (1997). Política pública e agricultura familiar: uma leitura do PRONAF. Rio de Janeiro: Estudos Sociedade e Agricultura.

CEDRO, M.; (2011). Pesquisa social e fontes orais: particularidades da entrevista como procedimentos metodológicos. Pelotas: Revista Perspectivas Sociais.

COLOGNESE, S. A.; MÉLO, J. L. B. de. (1998). A técnica de entrevista na pesquisa social. Porto Alegre: Cadernos de Sociologia.

CLEMENTE, E. C.; (2011). O programa de microbacias hidrográficas no contexto do desenvolvimento rural da Região de Jales/SP. Presidente Prudente. FCT-UNESP (Tese, doutorado em Geografia Agrária).

GRAZIANO DA SILVA, J.; DEL GROSSI, M. E. (2000). A evolução da agricultura familiar e do agribusiness nos anos 90. In: RATTNER, H.. (Org.). Brasil no limiar do século XXI: alternativas para a construção de uma sociedade sustentável. São Paulo: Editora da Universidade de São Paulo, p. 139-157.

GRISA, C.; V. J. WESZ JUNIOR; V. D. BUCHWEITZ. (2014). Revisitando o Pronaf: velhos questionamentos, novas interpretações. Piracicaba: Revista de Economia e Sociologia Rural, p. 323-346.

GUANZIROLLI, C. E. (2007). PRONAF dez anos depois: resultados e perspectivas para o desenvolvimento rural. Rio de Janeiro: Revista de Economia e Sociologia Rural, p. 301-328.

HESPANHOL, A. N. (2008). Desafios da geração de renda em pequenas propriedades e a questão do Desenvolvimento Rural Sustentável no Brasil. In: ALVES, A. F.; CARRIJO, B. R.; CANDIOTTO, L. Z. P. [Orgs] Desenvolvimento Territorial e Agroecologia. São Paulo: Expressão Popular, p. 81-93.

(2010b). A incorporação da perspectiva do desenvolvimento territorial nas políticas públicas brasileiras: avanços e limites. In: CUNHA, L.; PASSOS, M. M dos.; JACINTO, R. [Orgs] As Novas Geografias dos Países de Língua Portuguesa: paisagem, território, políticas no Brasil e em Portugal. Portugal: $1^{a}$ ed. Guarda: Centro de Estudos Ibéricos, p. 307 - 322.

(2010a). O Programa de Microbacias Hidrográficas no contexto da agropecuária no Pontal do Paranapanema - SP. Campo Grande: CONGRESSO BRASILEIRO DE ECONOMIA EOCIOLOGIA RURAL (SOBER).

LEAL, G. M. (2003). Impactos socioterritoriais dos assentamentos rurais do município de Teodoro Sampaio - SP. Presidente Prudente. FCT-UNESP (Dissertação, mestrado em Geografia Agrária).

MATTEI, L. (2007). Políticas de Apoio ao Desenvolvimento da Agricultura Familiar no Brasil: O Caso Recente do Pronaf. Documentos técnico-científicos. Fortaleza: Revista Econômica do Nordeste, p. 143157.

(2011). Evolução do crédito do PRONAF para as categorias de agricultores A e A/C entre 2000 e 2010. Belo Horizonte: CONGRESSO DA SOCIEDADE BRASILEIRA DE ECONOMIA, ADMINISTRAÇÃO E SOCIOLOGIA RURAL.

(2014). Evolução do crédito do PRONAF para as categorias de agricultores familiares A e A/C entre 2000 e 2010. Fortaleza: Revista Econômica do Nordeste, p. 58-69.

NIEDERLE, P. A. (2014). A agricultura familiar entre o setorial e o territorial? Novos referenciais para as políticas de desenvolvimento rural no Brasil. Costa Rica: Lume Repositorio digital - Perspectivas Rurales. Nueve época, p. 11- 35 .

ORTEGA, A. C. (2008). Territórios Deprimidos: desafios para as políticas públicas de desenvolvimento rural. Campinas- SP: Editora Alínea.

SCHNEIDER, S.; CAZELLA, A.; MATTEI, L. (2004). Histórico, caracterização e dinâmica recente do PRONAF - Programa Nacional de Fortalecimento da Agricultura Familiar. In: SCHNEIDER, S.; SILVA, M. K.; MARQUES, P. E. M. (Orgs) Políticas Públicas e participação social no Brasil Rural. Porto Alegre: UFRGS, p. 21-49.

SOUZA, P. M de et al. (2013). A distribuição dos contratos de crédito do Pronaf entre as unidades da federação no período de 1999 a 2010. Brasília: Revista de Economia e Sociologia Rural. p. 28-44.

SOUZA, S. P de. (2007). Assentamentos rurais e novas dinâmicas socioeconômicas: o caso dos municípios de Rosana, Euclides da Cunha Paulista e Teodoro Sampaio - SP. Presidente Prudente. FCT-UNESP (Dissertação, mestrado em Geografia Agrária).

VELOSO, F. (2011). Políticas públicas no Munícipio de Junqueirópolis (SP): Pronaf e PAA. Presidente Prudente. FCT-UNESP (Dissertação, mestrado em Geografia Agrária). 
VERGES, N. M. (2011). Financiamento do setor rural: uma análise dos Programas PROCERA e PRONAF e o caso dos assentamentos rurais do Pontal do Paranapanema - SP. São Paulo: Revista Agrária, p. 45-70.

\section{Sites consultados:}

FUNDAÇÃO IBGE de Caiuá e Teodoro Sampaio: banco de dados de 2010. Disponível em: <http://www.sidra.ibge.gov.br/>.

FUNDAÇÃO IBGE de Caiuá e Teodoro Sampaio: banco de dados de 2006. Disponível em: <http://www.sidra.ibge.gov.br/>.

DATA LUTA de Caiuá e Teodoro Sampaio: banco de dados 2010. Disponível em:< http://www2.fct.unesp.br/nera/> . 